\author{
JURNAL Midwifery Update (MU) \\ http://jurnalmu.poltekkes-mataram.ac.id/index.php/jurnalmu \\ e-ISSN: 684-8511 (Online)
}

\title{
REVIEW LITERATUR : PENGARUH PEMBERIAN AROMATERAPI LEMON TERHADAP EMESIS GRAVIDARUM
}

\author{
Rr Catur Leni Wulandari ${ }^{1}$, Rini Sulistyowati ${ }^{2}$ \\ ${ }^{1,2}$ Program Studi Kebidanan Program Sarjana dan Pendidikan Profesi Bidan Fakultas Kedokteran Universitas \\ Islam Sultan Agung
}

\begin{abstract}
Abstrak
Pendahuluan:Mual muntah (Emesis Gravidarum) sering terjadi pada ibu hamil trimester 1.Penyebabnya karena peningkatan hormon estrogen dan HCG pada awal kehamilan. Salah satu dampaknya yaitu Dehidrasi yang mengakibatkan janin mengalami masalah maka dari itu diperlukan terapi. salah satu terapi untuk menangani yaitu dengan aromaterapi lemon. Metode: Literatur mancanegara ditelusuri melalui sarana elektronik dengan penuntun kata kunci (emesis, terapi lemon, aromaterapi). Artikel seleksi berjumlah 8 tentang pengaruh aromaterapi lemon terhadap emesis gravidarum Hasil: adanya perbedaan emesis gravidarum pada pemberian aromaterapi dengan perlakuan yang sama. Pembahasan : salah satu penanganan untuk emesis gravidarum yaitu dengan caranonfarmakologis yaitu dengan pemberian aromaterapi lemon. Aroma terapi lemon mengandung limonene 66$80 \%$, geranil asetat, nerol, linalil asetat, pinene $0,4-15 \%$, pinene $1-4 \%$, terpinene $6-14 \%$ dan myrcen. Senyawa kimia seperti geranil asetat, nerol yang bermanfaat untuk antidepresi, nantiseptik, antispasmodik meredakan perasaan cemas, stres, dan lelah. Kesimpulan : pemakaian aromaterapi lemon efektif untuk mengurangi terjadinya emesis gravidarum
\end{abstract}

Kata Kunci : emesis, terapi lemon, aromaterapi

\begin{abstract}
Introduction: Nausea and vomiting (Emesis Gravidarum) often occurs in 1st trimester pregnant women. The cause is due to an increase in the hormones estrogen and HCG in early pregnancy. One of the effects is dehydration which causes the fetus to experience problems, therefore therapy is needed. one of the therapies to deal with is the aroma therapy of lemon. Methods: International literature searched by electronic means with key words (emesis, lemon therapy, aromatherapy). 8 selection articles on the effect of lemon aromatherapy on emesis gravidarum Results: there were differences in emesis gravidarum in aromatherapy with the same treatment. Discussion: one of the treatments for emesis gravidarum is a non-pharmacological method, namely lemon aromatherapy. Aromatherapy lemon therapy contains $66-80 \%$ limonene, geranil acetate, nerol, linalyl acetate, $0.4-15 \%$ pinene, $1-4 \%$ pinene, $6-14 \%$ terpinene and myrcen. Chemical compounds such as geranil acetate, nerol are useful for antidepressants, nantiseptics, antispasmodics to relieve feelings of anxiety, stress, and fatigue. Conclusion: the use of lemon aromatherapy is effective in reducing the occurrence of emesis gravidarum
\end{abstract}

Keywords: emesis, lemon therapy, aromatherapy 


\section{Pendahuluan}

Emesis Gravidarum sering terjadi pada ibu hamil trimester 1. Penyebabnya karena peningkatan hormon estrogen dan HCG pada awal kehamilan. Salah satu dampaknya yaitu Dehidrasi yang mengakibatkan janin mengalami masalah maka dari itu diperlukan terapi. salah satu terapi untuk menangani yaitu dengan aroma terapi lemon.

Hasil laporan menunjukkan bahwa hampir 50 - 90\% wanita hamil mual muntah terjadi pada trimester pertama. Keadaan ini akan membaik pada usia kehamilan 12-16 minggu. Keadaan ini terjadi pada sekitar $60-80 \%$ primigravida dan $40-60 \%$ terjadi pada multigravida (Winkjosastro, 2010). Studi prospektif pada 160 wanita oleh Lacroix et al. (2000), menemukan bahwa $74 \%$ melaporkan mual walaupun hanya $1,8 \%$ mengalami sebagai gejala yang hanya terjadi di pagi hari, pada $80 \%$ penderita, mual dapat berlangsung sepanjang hari dan Power et al. (2001), mencatat sekitar 51,4 \% wanita mengalami mual dan 9,2\% wanita mengalami muntah (Tiran, 2009).

Mual muntah pada kehamilan memiliki dampak yang signifikan bagi tubuh dimana ibu menjadi sangat lemah, muka pucat dan frekuensi buang air kecil menurun drastis sehingga cairan tubuh semakin berkurang dan darah menjadi kental (hemokonsentrasi). Keadaan ini dapat memperlambat peredaran darah sehingga suplay oksigen dan makanan ke jaringan juga ikut berkurang hal ini dapat menimbulkan kerusakan jaringan yang membahayakan kesehatan ibu dan janin. Prinsip penatalaksanaan emesis gravidarum meliputi pencegahan, mengurangi mual muntah, serta koreksi kebutuhan cairan dan elektrolit. Penanganan mual muntah dapat dilakukan dengan cara farmakologi maupun non farmakologi. Penanganan secara farmokologi dilakukan dengan cara mengkonsumsi obat-obatan seperti obat anti metik atau vitamin B6, namun obat- obatan ini memiliki efek samping yang kemungkinan dialami oleh ibu hamil seperti ; sakit kepala, diare dan mengantuk. Penatalaksanaan lain yang bisa diberikan adalah secara non farmakologi atau terapi komplementer yang mempunyai kelebihan lebih murah dan tidak mempunyai efek samping farmakologi, salah terapi yang aman dan bisa diberikan pada ibu hamil yang mengalami mual muntah dengan memberikan aromaterapi lemon (Laura, 2009)

Aromaterapi lemon adalah minyak essensialyang dihasilkan dari ekstrak kulit jeruk (CitrusLemon) yang sering digunakan dalam aromaterapi. Aromaterapi lemon adalah jenis aromaterapi yang aman untuk kehamilan dan melahirkan (Medforth et al.,2013). Aromaterapi lemon memiliki kandungan yang dapat membunuh bakteri meningokokus (meningococcus), bakteri tipus, memiliki efekanti jamur dan efektif untuk menetralisir bau yang tidak menyenangkan, serta menghasilkan efek anti cemas, anti depresi, anti stres, dan untuk mengangkat dan memfokuskan pikiran (Saridewi, 2018). Minyak esensial Lemon merupakan minyak herbal yang paling banyak digunakan dan dianggap sebagai obat yangaman pada kehamilan. Aromaterapi lemon terbukti memiliki efek menguntungkan pada emesis gravidarum. Menurut penelitian Kia (2013) skor rata-rata emesis gravidarum menurun selama empat hari menggunakan aromaterapi lemon i. Hal ini juga sesuai dengan penelitian yang dilakukan oleh Erick et al dengan melakukan pengamatan penggunaan perawatan non-farmakologis pada wanita untuk menghilangkan emesis gravidarum. Berdasarkan hasil penelitian tersebut menunjukkan bahwa $40 \%$ wanita menggunakan aroma lemon untuk meredakan mual muntah, dan lebih dari setengah dari mereka yang pernah menggunakannya mengatakan cara tersebut efektif.

\section{Metode Penelitian}

Pada metode penelitian ini pencarian jurnal dilakukan melalui google scholar, PubMad, BioMad Central, NEJM. Tujuan dari Literatur Review ini adalah untuk memecahkan masalah mengenai Emesis Gravidarum melalui pemberian Aromaterapi Lemon. Kata kunci yang dipakai dalam masalah ini adalah "giving lemon aromatherapy to the incidence of emesis gravidarum". Cara yang digunakan dalam mencari artikel ini adalah menggunakan bahasa inggris dan bahasa indonesia yang relevan. Artikel yang 
diperoleh di review untuk memilih artikel yang sesuai kriteria. Dan artikel yang didapatkan berjumlah 8 artikel dimana 5 jurnal internasional dan 3 artikel nasional, selanjutnya akan direview.

Artikel jurnal yang dilakukan oleh Umu Fauzah yang berjudul "Pengaruh Pemberian Aromaterapi InhalasiLemon Terhadap Emesis Gravidarum Pada Ibu Hamil Trimester I Di Puskesmas Umbulharjo I Kota Yogyakarta" menggunakan metode menggunakan jenis penelitian Quasi Experiment dengan desain penelitian yang digunakan adalah desain penelitian pretest posttest dengan kelompok control (pretest posttest with control group). Model rancangan ini menggunakan kelompok pembanding (kontrol). Pada penelitian ini dilakukan pengukuran pada kedua kelompok sebelum dan setelah diberi intervensi/perlakuan, kemudian dilakukan perbandingan keadaan sebelum dan setelah diberikan intervensi. Populasi dalam penelitian ini berjumlah $30 \mathrm{ibu}$ hamil yang mengalami emesis gravidarum dengan 15 kelompok kontrol dan 15 kelompok eksperimen. Penelitian ini menggunakan non random sampling atau disebut juga dengan non probability sampling, yaitu dengan tehnik Accidental sampling, dimana pengambilan sampel berdasarkan kebetulan, yaitu siapa saja yang secara kebetulan / incidental bertemu dengan peneliti dapat digunakan sebagai sampel. Dalam penelitian ini, sampelyang ditetapkan adalah 30 orang. Lima belas orang responden sebagai kelompok eksperimen dan 15 orang responden sebagai kelompok kontrol. Alat pengumpulan data yang digunakan adalah lembar pengumpulan data berupa kuesioner yang terdiri dari nama, umur, gravida, usia kehamilan, keluhan yang dirasakan, diagnosa, terapi yang diberikan, skore mual muntah. Analisa data yang digunakan adalah uji statistik parametrik paired sample $\mathrm{t}$ - test dengan batas kemaknaan $\mathrm{p}$ value $<0,05$ dan uji statistik parametrik independent sample $\mathrm{t}$ - test dengan batas kemaknaan $\mathrm{p}$ value $>0,05$.

Artikel jurnal yang dilakukan oleh Fitrianingsih dan Siti Khatijah 2019 yang berjudul "Efektifitas Aromaterapi Lemon untuk Menangani Emesis Gravidarum" menggunakan metode Rancangan penelitian yang digunakan yaitu Quasi experiment dengan one group pre-post test design. Penelitian dilaksanakan pada bulan April 2019 di Kecamatan Berbah Sleman Yogyakarta. Populasi penelitian yaitu ibu hamil yang mengalami emesis gravidarum. Jumlah sampel sebanyak 20 ibu hamil yang diambil dengan teknik purposive sampling. Kriteria inklusi dalam pengambilan sampel yaitu ibu hamil trimester pertama, ibu hamil yang mengalami mual muntah, ibu tidak alergi terhadap essensial oil Lemon dan tidak mempunyai penyakit yang berhubungan dengan gastrointestinal. Kriteria eksklusi penelitian yaitu ibu yang menggunakan intervensi lain untuk mengurangi mual muntah dan ibu yang tidak menggunakan aromaterapi dalam 12 jam/gugur. Bahan yang diperlukan dalam penelitian adalah essensial oil Lemon. Konsentrasi aromaterapi lemon yang diberikan yaitu $10 \%$, konsentrasi pemberian aromaterapi lemon didasarkan pada penelitian Kaviani et al. (2014).

Metode pengumpulan data diawali dengan menanyakan kuesioner untuk mengukur derajat mual muntah sebelum diberikan perlakuan dan mengisikan jawaban responden pada lembar kuesioner. Alat ukur dalam penelitian ini adalah Indeks RHODES berdasarkan skor yang diperoleh atas jawaban responden tentang kejadian mual muntah yang dialami. Selanjutnya peneliti memberikan aromaterapi lemon kepada ibu hamil untuk mencoba membau dan menjelaskan cara melakukan intervensi yaitu dengan menghirup kapas yang telah diberikan minyak esesnsial lemon pada saat mengalami mual dan atau muntah selama 5 menit dengan jarak sekitar $2 \mathrm{~cm}$ dari hidung, setelah 48 jam kemudian dilanjutkan dengan menanyakan kembali derajat mual muntah setelah dilakukan intervensi. Data dianalisis menggunakan uji Paired t-test.

Hasil penelitian Lacasse (2014, dalam Tiran, 2014) di Kanada dari 367 wanita hamil, 78, 47\% mual muntah terjadi pada trimester pertama dengan derajat mual muntah yaitu 52,2\% mual muntah ringan, 45,3 sedang dan 2,5\% berat. Pada trimester kedua 40,1\% wanita masih mual muntah dengan rincian $63,3 \%$ dan $0,8 \%$ mual muntah berat. Sesuai dengan evidence based practice. Bidan adalah salah satu tenaga kesehatan yang memberikan pelayanan obstetric, salah satunya dengan memberikan pelayanan pemeriksaan ibu hamil untuk mengetahui keadaan ibu dan janin. Dalam melakukan 
pelayanan Antenatal Care (ANC) hendaknya selalu memberikan penjelasan dan motivasi mengenai yang dirasakan ibu hamil termasuk mual muntah

Artikel jurnal penelitian ini dilakukan oleh Siti Cholifah dan Titin Eka Nuriyanah yang berjudul "Aromaterapi Lemon Menurunkan Mual Muntah pada Ibu Hamil Trimester I" pada penelitian ini menggunakan metode Rancangan penelitian yang digunakan Quasi experiment dengan One Group PrePost Test Design, Populasi ibu hamil trimester I yang mengalami mual muntah, pengambilan sampel dengan consecutive sampling sebanyak 36 ibu di 2 BPM yang ada di Kabupaten Sidoarjo yang memenuhi kriteria inklusi bersedia diteliti, hamil normal usia kehamilan $<12$ minggu dan kriteria eksklusi grande multigravida. Mulai tanggal 16 Desember 2017 sampai 16 Januari 2018. Mual muntah diukur sebelum dan sesudah pemberian aromaterapi lemon dengan Indeks Rhodes. Konsentrasi aromaterapi lemon yang diberikan dengan mencampurkan $0,1 \mathrm{ml}$ minyak esensial lemon kedalam air sebanyak $1 \mathrm{ml}$, konsentrasi pemberian aromaterapi lemon didasarkan pada penelitian Kaviani et al. (2014) kemudian ibu menghirup aromaterapi lemon yang ditaruh dalam kapas dengan jarak kurang lebih $2 \mathrm{~cm}$ dari hidung sambil bernafas panjang selama +5 menit dan bisa diulang jika masih merasa mual muntah. Kemudian di evaluasi setelah 12 jam.

Artikel jurnal penelitian yang dilakukan oleh Parisa Yavari kia ; Farzaneh Safajou ; Mahnaz Shahnazi ; Hossein Nazemiyeh dengan judul "The Effect of Lemon Inhalation Aromatherapy on Nausea and Vomiting of Pregnancy: A Double-Blinded, Randomized, Controlled Clinical Trial" pada tahun 2014 This was a randomized clinical trial in which 100 pregnant women with nausea and vomiting who had eligibility criteria were randomly divided into intervention and control groups based on four- and six-random block sampling method. Lemon essential oil and placebo were given to the intervention and control groups, respectively, to inhale it as soon as they felt nausea. The nausea, vomiting, and retch intensity were investigated 24 hours before and during the four days of treatment by means of PUQE24

Results: There was a statistically significant difference between the two groups in the mean scores of nausea and vomiting on the second and fourth days $(\mathrm{P}=0.017$ and $\mathrm{P}=0.039$, respectively). The means of nausea and vomiting intensity in the second and fourth days in the intervention group were significantly lower than the control group. In addition, in intragroup comparison with ANOVA with repeated measures, the nausea and vomiting mean in the five intervals, showed a statistically significant difference in each group.

Artikel jurnal penelitian yang dilakukan oleh Ismail BIYIK, Fatih KESKIN yang berjudul "The Lollipop with Lemon Aroma May Be Promising in Nausea and Vomiting in Pregnancy" menggunakan desain Studi kasus-kontrol prospektif ini dilakukan di dua pusat; Rumah Sakit Negara Bagian Bursa Karacabey dan Mustafakemalpasa antara Juni 2016 dan Agustus 2018 dan telah disetujui oleh Komite Etika Rumah Sakit Penelitian dan Pelatihan Spesialisasi Tinggi Bursa dan persetujuan tertulis yang diinformasikan diperoleh dari setiap peserta. Penelitian dilakukan sesuai dengan Deklarasi Helsinki yang dibutuhkan. Daya 81\%, Kehamilan -Kuantifikasi Unik Emesis dan Nausea (PUQE) skor kelompok studi dan kontrol di awal dan hari pertama adalah 1,23, tingkat signifikansi (alpha) 0,05, koefisien variasi pada skala asli 0,3 dan ukuran sampel $33+33$ dihitung dengan program PASS 11 . Kelompok yang akan dimasukkan dalam pasien pertama yang memenuhi kriteria inklusi ditentukan dengan metode acak sederhana. Oleh karena itu, kelompok kontrol 1 pasien dan pasien 2 dimasukkan dalam kelompok studi. Pasien dengan angka ganjil dimasukkan ke dalam kelompok kontrol dan pasien dengan angka genap dimasukkan ke dalam kelompok penelitian. Studi tersebut melibatkan wanita berusia 18-45 tahun dengan kehamilan tunggal antara 6-14 minggu. Minggu kehamilan ditentukan menurut tanggal periode menstruasi terakhir. Jika ada perbedaan lebih dari 1 minggu antara tanggal menstruasi terakhir dan pengukuran ultrasonografi, maka pengukuran ultrasonografi diterima dalam menentukan minggu kehamilan. Diagnosis NVP adalah diagnosis eksklusi seperti: Pasien dengan kehamilan ganda, kehamilan mola, atau penyakit sistemik (pankreatitis, hepatitis, kolesistitis, dll.) Yang 
dapat menyebabkan mual dan muntah, mereka yang dicurigai keracunan makanan, pasien yang menderita mual akibat penyakit kejiwaan, dan wanita dengan hiperemesis gravi- darum dikeluarkan dari penelitian. Hamil dengan penurunan berat badan lebih dari $>5 \%$, temuan dehidrasi, ketosis, dan kelainan elektrolit diterima sebagai hiperemesis.

Artikel jurnal penelitian yang diteliti oleh Dr. Arshi Anjum, Dr. Kouser Fathima Firdose, Dr.Wajeeha Begumdengan judul "Effect of Sikanjabeen Lemooni in Qay'al-Haml: An Open Observational Study" menggunakan jenis penelitian study Studi observasi terbuka dilakukan dari Januari 2017 hingga Desember 2017 di Dept. OBG National Institute of Unani Medicine hospital, Bengalurus. Ukuran sampel dihitung dengan menggunakan rumus, $\mathrm{n}=2[(\mathrm{Z} \alpha-\mathrm{Z} \beta) \times \sigma] 2 /(\mu 1-\mu 2)$ 15 di sekitar perbedaan rata-rata PUQE dari dua perkiraan. Mean dan SD dari PUQE diambil dari penelitian sebelumnya. $\mathrm{n}=$ jumlah sampel yang dibutuhkan, $\mu 1=$ skor rata-rata sebelum pengobatan, $\mu 2=$ skor rata-rata setelah pengobatan, $\mu 1-\mu 2=$ perbedaan signifikan secara klinis, $\sigma=$ deviasi standar. Besar sampel yang dihitung adalah 27,08 ; mengingat $10 \%$ putus sekolah, total ukuran sampel diambil 30. Wanita hamil dengan c / o mual dan muntah dengan kehamilan intrauterin tunggal dalam usia kehamilan 7 sampai 14 minggu diikutsertakan dalam penelitian. Wanita dengan hiperemesis gravidarum, diobati dengan antiemetik lain, dengan kondisi medis yang berhubungan dengan kehamilan seperti anemia berat, hipertensi dan diabetes mellitus dan dengan riwayat penyebab muntah nonobstetris lainnya seperti kolesistitis dan apendisitis dikeluarkan dari penelitian dengan melakukan $\mathrm{Hb} \%$, RBS, CUE, USG-kebidanan.Total 68 pasien diskrining; 3 pasien tidak memenuhi syarat karena HG. Dari 65 pasien yang memenuhi syarat; 22 menolak untuk berpartisipasi dan 13 dikeluarkan; 1 pasien diaborsi sebelum pengobatan dimulai, 1 mengalami kehamilan kembar, pada 2 pasien masing-masing usia kehamilan $>14$ minggu dan $\mathrm{Hb} \%<11 ; 3$ menderita hipotiroidisme dan 4 pasien menderita ISK. 30 pasien dilibatkan dalam penelitian ini.

Artikel jurnal penelitian ini diteliti oleh Masoumeh Namazi ; Seddigheh Amir Ali Akbari; Faraz Mojab ; Atefe Talebi ; Hamid Alavi Majd ; Sharareh Jannesari dengan judul "Aromatherapy With Citrus Aurantium Oil and Anxiety During the First Stage of Labor". Penelitian ini menggunakan metode Uji klinis acak ini dilakukan pada dua kelompok wanita hamil, yang dirujuk ke Rumah Sakit Vali-Asr (Tuyserkan, Iran) antara Juni dan September 2013. Itu terdaftar di Registri Uji Klinis Iran (IRCT ID: N6 201301306807). Mempertimbangkan penelitian serupa, interval kepercayaan 95\%, dan probabilitas kesalahan 5\%, ukuran sampel dihitung sebagai 63 subjek di setiap kelompok. Wanita pertama kali diberi pengarahan tentang tujuan dan metode penelitian dan kemudian diminta untuk memberikan persetujuan tertulis jika mereka bersedia untuk berpartisipasi. Wanita hanya dilibatkan jika mereka adalah orang Iran, primipara, dan berusia 18-35 tahun, memiliki cukup bulan, kehamilan tunggal, presentasi kepala, kontraksi spontan, pelebaran serviks 3-4 cm saat persalinan, kondisi pinggul yang baik dan kantung ketuban utuh., tidak menggunakan obat analgesik dalam delapan jam terakhir, dan tidak memiliki penyakit hati, kandung empedu, atau pernapasan dalam catatan mereka. Orang dengan gangguan penciuman, alergi terhadap obat-obatan herbal, atau mengalami komplikasi kehamilan (misalnya, preeklamsia, korioamnionitis, solusio plasenta, dan detak jantung janin yang abnormal pada saat penelitian) tidak dimasukkan. Data dikumpulkan dengan menggunakan kuesioner demografi dan kebidanan, daftar periksa pemeriksaan dan observasi termasuk tanda-tanda vital, pemeriksaan vagina, kontraksi uterus, dan detak jantung janin, dan kuesioner kecemasan ciri-ciri keadaan Spielberger. Kesesuaian dari dua alat pertama diuji melalui validitas konten. Selain itu, reliabilitas daftar periksa telah disetujui dengan menggunakan reliabilitas bentuk paralel $(\mathrm{r}=0.85)$. Setelah menyelesaikan dua instrumen pertama, tingkat keparahan kecemasan dinilai dengan 20 item dari pertanyaan kecemasan yang disebutkan. Karena setiap item diberi skor 1-4, skor kecemasan total berkisar antara 20 dan 80 (20-40, kecemasan ringan; 41-60, kecemasan sedang; 61-80, kecemasan parah). Kuesioner ini banyak digunakan untuk mengukur kecemasan sifat-negara dalam studi klinis $(11,22-24)$ dan memiliki koefisien korelasi 0,85-0,91 (25). 
Kriteria eksklusi adalah alergi atau intoleransi, komplikasi kehamilan seperti perdarahan vagina selama penelitian, dan sesar darurat sebelum penelitian selesai. Tabel jumlah acak digunakan untuk secara acak mengalokasikan wanita yang memenuhi syarat untuk aromaterapi dan kelompok kontrol (n = 63 masing-masing). Konsentrasi distilat yang dibeli (Iran-Gereban Co., Iran) ditentukan dengan metode gravimetri di Sekolah Farmasi, Shahid Beheshti University of Medical Sciences (Teheran, Iran). Tiap $100 \mathrm{~mL}$ hasil destilat mengandung $8 \mathrm{~mL}$ minyak esensial. Kain kasa diresapi dengan $4 \mathrm{~mL}$ distilat dan saline normal ditempelkan pada kerah peserta dalam aromaterapi dan kelompok kontrol. Kain kasa diganti setiap 30 menit. Intensitas kecemasan pada kedua kelompok diukur pada awal dan setelah intervensi pada pembukaan 3-4 dan 6-8 cm. Analisis data dilakukan dengan SPSS for Windows versi 22.0 (SPSS Inc., Chicago, IL, USA). Statistik deskriptif termasuk tendensi sentral, dispersi, dan distribusi frekuensi digunakan untuk menggambarkan kedua kelompok tersebut. Chi-square dan uji Fisher diterapkan untuk membandingkan variabel kualitatif antara kelompok. Variabel kuantitatif dibandingkan dengan menggunakan uji-t independen. Perbandingan dari kedua kelompok dalam hal variabel kualitatif dengan distribusi non-normal dan variabel ordinal dilakukan dengan menggunakan uji Mann-Whitney nonparametrik. Akhirnya, uji Kolmogorov-Smirnov dilakukan untuk memeriksa distribusi normal subjek .

Artikel jurnal yang dilakukan oleh Narges Joulaeerad, Giti Ozgoli, and Fatemeh Salehimoghaddam dengan judul "Effect of Aromatherapy with Peppermint Oil on the Severity of Nausea and Vomiting in Pregnancy: A Single-blind, Randomized, Placebo-controlled trial pada tahun 2015 Penelitian ini merupakan uji klinis terkontrol plasebo acak tersamar tunggal yang dilakukan pada 56 wanita hamil dengan keluhan NVP, yang dirujuk ke pusat kesehatan terpilih Shahid Beheshti University of Medical Sciences di Teheran dari Desember 2014 hingga akhir Mei 2015. .

Kriteria inklusi adalah usia 18 sampai 35 tahun, orang Iran dan minimal berpendidikan cukup baca tulis, tingkat dasar NVP ringan sampai sedang (skor 3 sampai 12) berdasarkan skor yang diperoleh dari kuesioner PUQE sebelum intervensi, 6 hingga usia kehamilan 20 minggu berdasarkan hari pertama periode menstruasi terakhir (LMP) atau ultrasound trimester pertama, memiliki setidaknya satu laporan ultrasound untuk menentukan jumlah dan kesehatan janin, kehamilan yang diinginkan menurut individu, kekurangan Masalah penciuman menurut individu, kehamilan tunggal normal dalam segala hal dan tidak ada riwayat komplikasi kebidanan pada kehamilan saat ini (tidak memiliki gejala aborsi terancam, kurang kehamilan mola), ibu hamil yang sehat dalam segala hal dan tidak ada riwayat penyakit yang diketahui. berdasarkan informasi dari catatan profil kesehatan ibu, tidak merokok dan konsumsi alkohol, ketidakpekaan terhadap jamu menurut individu, tidak mengkonsumsi obat antiemetik kimia dan herbal dalam 24 jam sebelum studi dimulai, tidak mengalami gangguan kesehatan mental dan kesialan dalam enam bulan sebelum studi dimulai.

Selain itu, peserta dikeluarkan dari penelitian jika terjadi mual dan muntah yang parah selama kehamilan (skor 13 atau lebih tinggi pada kuesioner PUQE), sensitivitas terhadap minyak esensial peppermint atau intoleransi aroma peppermint, mengonsumsi obat-obatan antiemetik atau obat herbal selama kehamilan. masa studi, pelaksanaan aromaterapi kurang dari tiga kali dalam sehari, terjadinya gejala ancaman aborsi selama masa studi, dan keengganan untuk terus berpartisipasi dalam penelitian.

Alat yang digunakan dalam penelitian ini termasuk tiga kuesioner: (1) Kuesioner demografi dan kebidanan; (2) kuesioner PUQE; dan (3) Kuesioner akhir. Kuesioner demografi dan kebidanan terdiri dari dua bagian yaitu informasi latar belakang dan riwayat kebidanan yang diisi oleh peneliti untuk masing-masing wanita. Kuesioner PUQE yang berisi tiga pertanyaan tentang durasi mual, jumlah muntah dan frekuensi muntah $(22,23)$. Ini digunakan untuk menentukan tingkat dasar NVP dan tingkat keparahannya selama masa studi.

Kuesioner terakhir digunakan untuk mengevaluasi kepuasan pasien dari pengobatan, kepatuhan terhadap rekomendasi kesehatan dan gizi, dan evaluasi perubahan gejala secara umum dari sudut pandang wanita hamil. 
Validitas isi kuesioner akhir dievaluasi. Selain itu, reliabilitas kuesioner PUQE dengan koefisien korelasi 0,9 ditentukan dengan menggunakan metode tes-tes ulang.

Artikel jurnal penelitian yang dilakukan oleh Rahajeng Siti Nur Rahmawati, Indah Rahmaningtyas, Trinanda Qonitah dengan judul "aromaterapi lemon Untuk Menurunkan Emesis Gravidarum". Pada metode ini menggunakan Jenis penelitian ini adalah penelitian kuantitatif dengan desain perbandingan, dimana terdapat 2 kelompok yang mendapat satu intervensi berbeda yaitu pemberian minuman jahe panas dan minuman jeruk nipis. Sebelum diberikan intervensi akan diberikan pretest dan setelah dilakukan intervensi akan diberikan posttest. Desain penelitian adalah membedakan kelompok terhadap prosedur kerja. Pemberian jahe panas dengan komposisi: jahe emprit (Zingiber officinale, jenis jahe terkecil dan terpanas di Indonesia) diiris 2 gram, gula 1 sendok makan, dan $250 \mathrm{ml}$ air hangat dengan suhu 60-700C, diberikan $2 \times 1$ sehari selama 4 hari . Pemberian jeruk nipis dengan komposisi: 1 buah jeruk nipis (Citrus limon) diameter 1,5-2,5 cm, 1 sendok makan gula pasir dan $250 \mathrm{ml}$ air hangat dengan suhu $60-700 \mathrm{C}$, diberikan $2 \times 1$ sehari selama 4 hari.

\section{Hasil dan Pembahasan}

1. Artikel jurnal yang dilakukan oleh Umu Fauzah yang berjudul "Pengaruh Pemberian Aromaterapi Inhalasi Lemon Terhadap Emesis Gravidarum Pada Ibu Hamil Trimester I Di Puskesmas Umbulharjo I Kota Yogyakarta Berdasarkan tabel 3 terlihat bahwa sebelum diberikan aromaterapi inhalasi lemon responden penelitian yang paling banyak berada pada kategori mual muntah sedang yaitu sebanyak 9 orang $(60.0 \%)$. Hasil penelitian menunjukkan berdasarkan tabel 3 terlih at bahwa sebelum diberikan aromaterapi inhalasi lemon responden penelitian paling banyak berada pada kategori mual muntah sedang yaitu sebanyak 9 orang $(60,0 \%)$ dan pada tabel 4.5 setelah diberikan aromaterapi inhalasi lemon responden penelitian paling banyak berada pada kategori tidak mual muntah yaitu sebanyak 13 orang $(86,67)$. Berdasarkan tabel 3 nilai $p$ value $=0,000<$ 0,05 maka dapat disimpulkan ada perbedaan signifikan pada responden sebelum dan sesudah pemberian aromaterapi inhalasi lemon pada kelompok eksperimen dimana nilai rata - rata intensitas mual muntah sebelum diberikan 12.80 dan sesudah diberikan nilai rata - rata mual muntah mengalami penurunan yaitu 3.07. Terlihat perbedaan nilai rata - rata antara sebelum dan sesudah adalah 9.733 dengan standart deviasi 4.061.

2. Artikel jurnal yang dilakukan oleh Fitrianingsih dan Siti Khatijah 2019 yang berjudul "Efektifitas Aromaterapi Lemon untuk Menangani Emesis Gravidarum"Berdasarkan tabel 3 nilai $\mathrm{p}$ value = $0,000<0,05$ maka dapat disimpulkan ada perbedaan signifikan pada responden sebelum dan sesudah pemberian aromaterapi inhalasi lemon pada kelompok eksperimen dimana nilai rata - rata intensitas mual muntah sebelum diberikan 12.80 dan sesudah diberikan nilai rata - rata mual muntah mengalami penurunan yaitu 3.07. Terlihat perbedaan nilai rata - rata antara sebelum dan sesudah adalah 9.733 dengan standart deviasi 4.061.Berbagai penelitian sejalan dengan hasil penelitian ini antara lian penelitian yang dilakukan oleh Rofi'ah (2019) bahwa terdapat perbedaan derajat emesis gravidarum pada ibu hamil antara sebelum dan setelah diberikan aromaterapi lemon, dimana tingkat emesis gravidarum sebelum diberikan aromaterapi lemon pada rentang skor $3-23$ dan tingkat emesis gravidarum sesudah diberikan aromaterapi lemon pada rentang skor $0-19$. Dalam penelitian tersebut juga membandingkan penggunaan aromaterapi dengan berbagai dosis yaitu $0,1 \mathrm{ml} ; 0,2 \mathrm{ml}$; dan $0,3 \mathrm{ml}$. Berdasarkan hasil penelitian tersebut tidak ada perbedaan efektivitas aromaterapi lemon diantara tiga dosis dalam mengatasi emesis gravidarum, namun jika dianalisa pada masing-masing kelompok diperoleh hasil bahwa aromaterapi lemon dosis 0.2 dan 0.3 efektif dalam mengatasi emesis gravidarum. Dengan demikian tenaga kesehatan, dosen atau tenaga pendidik sebagai pemberi pelayanan dan transfer agent of knowledge dapat menggunakan referensi 
dari berbagai hasil penelitian tentang manfaat aromaterapi lemon dalam mengatasi emesis gravidarum.

3. Artikel jurnal penelitian ini dilakukan oleh Siti Cholifah dan Titin Eka Nuriyanah yang berjudul "Aromaterapi Lemon Menurunkan Mual Muntah pada Ibu Hamil Trimester I" Berdasarkan hasil penelitian skor indeks Rhodes mual muntah sebelum diberikan aromaterapi lemon Mean \pm SD $23,33 \pm 3,91$, setelah diberikan aromaterapi lemon Mean \pm SD 13,67 \pm 4.071 skor indeks Rhodes dari kategori mual muntah sedang menjadi ringan, hasil analisis Wilcoxon Sign Rank Test terdapat penurunan secara signifikan skor indeks Rhodes mual muntah setelah ibu hamil menghirup aromaterapi lemon hasil $P$ value $=0,0001<\alpha=0,05$. Hasil penelitian ini didukung oleh penelitian Safajau, et al (2014) dengan hasil $p=0.0001$ aromaterapi inhalasi lemon secara efektif dapat menurunkan mual muntah pada ibu hamil. Selain itu penelitian Santi (2013) hasil uji didapatkan $p$ =Aromaterapi salah satu terapi nonfarmakologi pada saat ini mulai banyak digunakan di Inggris dan Eropa, dengan ketersediaan dilaporkan pada 76\% di departemen obstetri Jerman, aromaterapi baru-baru ini diperkenalkan ke AS rumah sakit dan klinik (Seol et al., 2010;. Horowitz, 2011; Conrad, 2010 in Smith V 2012). Aromaterapi lemon berasal dari ekstraksi kulit jeruk lemon (Citrus Lemon) merupakan salah satu jenis aromaterapi yang aman untuk kehamilan dan melahirkan (Medforth, 2013). Pada penelitian ini seluruh responden menyukai bau dari aromaterapi lemon. Minyak essensial lemon mengandung limonene $66-80 \%$, geranil asetat, nerol, linalil asetat, $\beta$ pinene $0,4-15 \%$, $\alpha$ pinene $1-4 \%$, terpinene $6-14 \%$ dan myrcen (Young, 2011). Senyawa kimia seperti geranil asetat, nerol, linalil asetat, memiliki efek antidepresi, antiseptik, antispasmodik, penambah gairah seksual dan obat penenang ringan (Namazi, et al, 2014)

4. Artikel jurnal penelitian yang dilakukan oleh Ismail BIYIK, Fatih KESKIN yang berjudul "The Lollipop with Lemon Aroma May Be Promising in Nausea and Vomiting in Pregnancy" Di antara minyak nabati dan aromaterapi alternatif non-farmakologis, minyak esensial jahe, peppermint, dan lemon digunakan untuk mencegah NVP (10-12). Efek anti-emetik lemon dikenal sejak lama dan sejauh ini tidak ada bahaya yang dilaporkan selama kehamilan $(13,14)$. Lemon dalam bentuk minyak atsiri (jeruk lemon) yang disiapkan untuk disebarkan di udara kamar tidur telah terbukti menurunkan NVP (15). Bau lemon dilaporkan dapat mengurangi gejala mual dan muntah sebanyak $40 \%$ (16). Smith dkk. melaporkan bau lemon segar efektif dalam mengurangi gejala NVP (17). Yavari Kia dkk. menyarankan bahwa menghirup lemon selama 4 hari efektif dalam mengurangi gejala NVP jika dibandingkan dengan kontrol (8).

Meskipun tidak diketahui bahwa mekanisme mual dan muntah akibat kemoterapi sama dengan NVP, telah dilaporkan bahwa kapsul oral Citrus aurantium menurunkan mual akibat kemoterapi pada pasien dengan kanker ovarium (18). Selain itu, Ozdemir et al. melaporkan bahwa pemberian lolipop dengan aroma stroberi kepada pasien yang menerima infus sel induk darah tepi cryopreserved (PBSC) selama transplantasi sumsum tulang mengurangi gejala mual dan muntah terkait pengobatan (9). Dimetil sulfoksida, bahan dari sel induk perifer autoligous cryopreserved (PBSC) diperkirakan mencapai permukaan mukosa seperti rongga mulut dan menyebabkan mual dan muntah berbau busuk seperti bawang putih. Cabang gustatorik dari saraf olpabrik dan fasia, saraf glossopharyngeal dan saraf vagus diperkirakan mengirimkan sinyal-sinyal ini ke hipotalamus dan sistem limbik. Mungkin mekanisme yang sama berlaku pada permen lolipop lemon. Diketahui bahwa keton yang diproduksi selama kelaparan jangka panjang diekskresikan melalui pernafasan dan buang air kecil dalam bentuk aseton halitosis dan ketonuria. Ekskresi keton melalui pernafasan dan ketonemia itu sendiri menyebabkan bau mulut yang tidak sedap, bau mulut, dan muntah yang selanjutnya menyebabkan kelaparan dan produksi keton kembali dalam lingkaran setan. Penghirupan aroma atau rasa aromatik dapat digunakan untuk menekan bau mulut dan memutus siklus ini. Penghirupan lemon diperkirakan menghasilkan efek ini oleh pusat penciuman melalui reseptor penciuman dan menyebabkan keadaan kesejahteraan fisik dan mental (8). Efek yang sama 
mungkin berlaku untuk hisapan aroma lemon dalam bentuk lolipop. Meskipun ada laporan bahwa menghirup lemon menurunkan NVP, tidak ada penelitian tentang efek pemberian oral dari lollipop rasa lemon. Lolipop sudah tersedia dan jauh lebih murah serta dapat diterima daripada minyak yang diberi rasa lemon. Oleh karena itu, kami menyelidiki efek lolipop rasa lemon (permen bulat dengan batang) pada kasus NVP dalam penelitian ini. Penurunan skor PQUE pada kelompok studi dibandingkan dengan kontrol

5. Artikel jurnal penelitian yang dilakukan oleh Parisa Yavari kia ; Farzaneh Safajou ; Mahnaz Shahnazi ; Hossein Nazemiyeh dengan judul "The Effect of Lemon Inhalation Aromatherapy on Nausea and Vomiting of Pregnancy: A Double-Blinded, Randomized, Controlled Clinical Trial" Menurut temuan penelitian ini, nilai rata-rata NVP menurun selama empat hari penggunaan aromaterapi lemon inhalasi; namun, penurunan skor ini signifikan secara statistik hanya pada hari kedua dan keempat masa tindak lanjut dalam dua kelompok. Penggunaan pengobatan komplementer dan alternatif (CAM) di Iran memiliki sejarah panjang dan bidan serta dokter tertarik untuk menggunakannya. Aromaterapi adalah metode yang selain memiliki efek fisik, memiliki efek psikologis (seperti relaksasi atau stimulasi) yang dapat berulang dengan sangat cepat. Penciuman di tingkat dasar yang paling rendah, dapat merangsang tubuh untuk merespons secara fisik dan psikologis. Ketika zat aromatik seperti minyak herbal mengeluarkan molekul bau, sel reseptor di hidung mengirimkan impuls langsung ke daerah penciuman di otak. Wilayah tersebut terkait erat dengan sistem lain yang mengontrol memori, emosi, hormon, seks, dan detak jantung. Denyut bekerja segera dan hormon yang dilepaskan mampu menstimulasi, menenangkan, menenangkan, atau menggembirakan orang tersebut, yang mengarah pada penciptaan perubahan fisik dan mental (10). Aromaterapi lemon dapat memiliki efek menguntungkan pada NVP (17). Hasil penelitian Pretest-Posttest di Indonesia, pada 12 ibu hamil dengan NVP menunjukkan bahwa terapi aroma lemon menurunkan NVP (18), hal ini sejalan dengan hasil penelitian ini. Erick dkk. menyelidiki penggunaan perawatan non-farmakologis oleh wanita untuk menghilangkan NVP. Hasil studinya menunjukkan bahwa $40 \%$ wanita menggunakan aroma lemon untuk meredakan NVP, dan $26,5 \%$ dari mereka yang menggunakannya menyatakan efektif(11).

6. Hasil studi oleh Pasha et al. yang menggunakan aromaterapi hirup peppermint untuk meredakan NVP pada 60 wanita hamil mencoba melaporkan bahwa pemulihan diperbaiki untuk menyenangkan peneliti, namun ternyata tidak benar. kemungkinan jenis bias ini mungkin lebih tinggi dalam uji coba bahwa plasebo hanya digunakan sebagai pengobatan. Penurunan signifikan pada skor mual dan muntah hanya pada hari kedua dan keempat antara kelompok mungkin disebabkan oleh respon yang berbeda oleh individu terhadap terapi aroma. Dengan kata lain, perawatan ini mungkin menyenangkan bagi sebagian orang dan mungkin tidak nyaman bagi orang lain. Dalam aromaterapi, pasien perlu menghirup bau tertentu berdasarkan keadaan psikososialnya, dan setiap individu akan bereaksi terhadap bau tertentu secara berbeda (19). Oleh karena itu, hal tersebut dapat dianggap sebagai salah satu keterbatasan dalam penelitian ini. Keterbatasan lain untuk penelitian ini adalah ketidakmampuan untuk mengontrol faktor psikologis selama intervensi. Salah satu kekuatan dari penelitian ini adalah penggunaan kuesioner PUQE-24 yang dirancang khusus untuk NVP. Kami belum menemukan uji klinis apa pun yang telah menguji efek terapi aroma Lemon pada NVP. Oleh karena itu, karena terbatasnya penelitian di bidang aromaterapi terhadap NVP, diperlukan penelitian lebih lanjut di bidang ini. Aromaterapi inhalasi dengan minyak esensial Lemon menunjukkan bahwa metode ini dapat mengurangi NVP. Berbeda dengan pengobatan kimiawi, terapi aroma memiliki efek yang berguna pada kesehatan fisik dan psikologis dan mungkin berguna sebagai pendekatan alternatif dalam pengobatan NVP.

Dari hasil review yang sudah dipaparkan adanya tingkat pemberian aromaterapi lemon terhadap kejadian emesis gravidarum. Menurut (Winkjosatro, 2010), bahwa hamil pada usia muda merupakan salah satu faktor penyebab terjadinya emesis gravidarum dalam kurun waktu reproduksi sehat bahwa 
usia untuk kehamilan dan persalinan adalah 20 - 30 tahun, kematian maternal pada wanita hamil dan melahirkan pada usia dibawah 20 tahun ternyata $2-3$ kali lebih tinggi daripada kematian yang terjadi padausia 20 - 35 tahun, kematian maternal meningkat kembali setelah usia 35 tahun, hal ini disebabkan menurunnya fungsi organreproduksiwanita.

\section{Kesimpulan}

Simpulan berdasarkan analisa yang telah dilakukan oleh penulis, disimpulkan bahwa penggunaan aromaterapi lemon mengurangi kejadian emesis gravidarum. Saran yang dapat diberikan untuk pelaksanaan literature review selanjutnya adalah sebaiknya database yang digunakan lebih banyak sehingga bisa mendapatkan artikel yang lebih banyak dan baik dan batasan tahun pencarian artikel dengan kata kunci yang ditetapkan adalah lima tahun terakhir.

\section{Daftar Pustaka}

1. Chan, R.L , et al .2011. Maternal Influences on Nausea and Vomiting in Early Pregnancy. NIH : Matern Child Health J. ; 15(1): 122- 127.doi:10.1007/s10995-009-0548-

2. Santi D, R. 2013. Pengaruh Aromaterapi Blended Peppermint dan Ginger Oil terhadap Rasa Mual pada Ibu Hamil Trimester Satu . Diperoleh tanggal 15 Juni 2017 jurnal Portal garuda. Smith, C.A., Collins, C.T. \& Crowther,

3. C.A. (2012) Aromatherapy for Pain Management in Labour (Review) The Cochrane collaboration,Publshers by John Wiley \& Sons, Ltd

4. Potts, J. (2009). Aromatherapy in Nursing Practice. Australian Nursing Journal 16, 11; ProQuest Research Library pg. 55.

5. Malek A. SN, Ibrahim H, Hong SL, Lee GS, Chan KS, Ma NA, "The essential oils of Zingiber officinale variants," Malaysian J Sci, 24(2), pp. 37- 43, 2005.

6. Smith C, Crowther C, Willson K, Hotham N, McMillian V., "A Randomized Controlled Trial of Ginger to Treat Nausea and Vomiting In Pregnancy,” Obstetric Gynecol. 103(4), pp. 639-45, 2004.

7. Palatty, Princy L., Raghavendra Haniadka, Bhavishya V., Rajesh A.a, and Manjeshwar S. Baliga, "Ginger in the Prevention of Nausea and Vomiting: A Review," Critical Reviews in Food Science and Nutrition (53), pp. 659-669 2013. 